\title{
At The Dramatists' Table: The Climax and Decline of a Mannerist Cuisine in England, 1580-1630
}

Gilly Lehmann

\section{(2) OpenEdition}

Journals

\section{Electronic version}

URL: http://journals.openedition.org/shakespeare/1693

DOI: 10.4000/shakespeare.1693

ISSN: 2271-6424

\section{Publisher}

Société Française Shakespeare

\section{Printed version}

Date of publication: 3 March 2012

Number of pages: $13-29$

ISBN: 2-9521475-8-2

\section{Electronic reference}

Gilly Lehmann, « At The Dramatists' Table: The Climax and Decline of a Mannerist Cuisine in England, 1580-1630 », Actes des congrès de la Société française Shakespeare [Online], 29 | 2012, Online since 03 March 2012, connection on 06 May 2019. URL : http://journals.openedition.org/shakespeare/1693 ; DOI : 10.4000/shakespeare.1693 


\section{Shakespeare et les arts de la table}

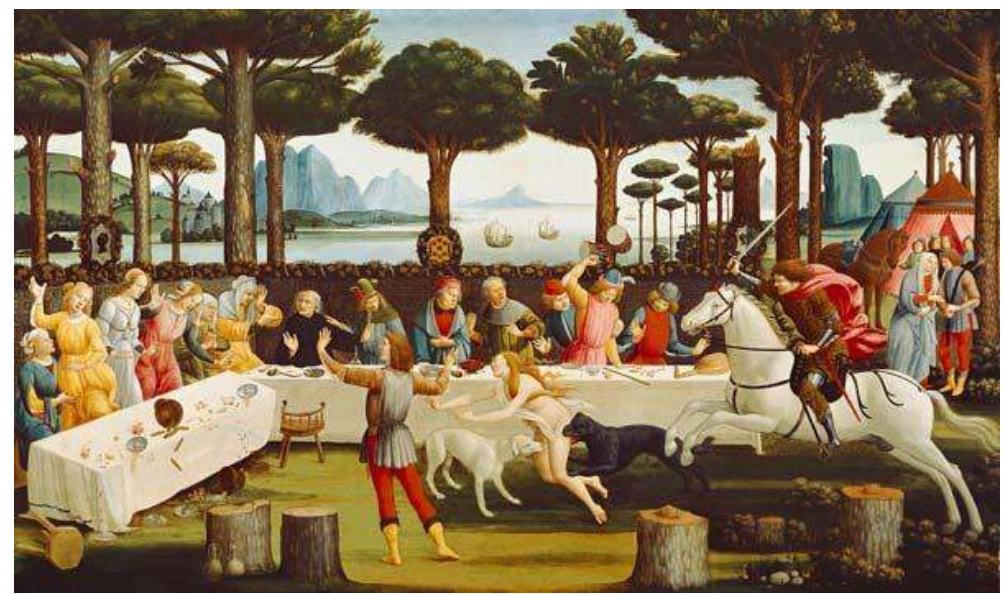

actes du Congrès

organisé par la

SOCIÉTÉ FRANÇAISE SHAKESPEARE

les 17, 18 et 19 mars 2011

textes réunis par

Christophe HAUSERMANN

et

Pierre KAPITANIAK

sous la direction de

Dominique GoY-BLANQUET 
COUVERTURE :

Botticelli, Banquet dans la forêt de pins,

Troisième tableau de la série

"L'histoire de Nastagio degli Onesti » inspiré d'une nouvelle du Décaméron de Boccace Musée du Prado, Madrid

conception graphique et logo

Pierre Kapitaniak

mise en page et corrections

Christophe Hausermann

Pierre Kapitaniak

(C) 2011 Société Française Shakespeare Institut du Monde Anglophone Université de Paris III - Sorbonne Nouvelle 5 rue de l'École de Médecine 75006 Paris

www.societefrancaiseshakespeare.org

Tous droits de traduction, de reproduction et d'adaptation réservés pour tous les pays 


\title{
At The Dramatists' Table: The Climax And DECline OF A MANNERIST CUISINE IN ENGLAND, 1580-1630
}

\author{
Gilly LEHMANN
}

Plays by Shakespeare and his contemporaries "teem" with episodes which place gastronomy centre-stage. Why? One of the reasons is that these playwrights were writing at a period when the fashionable culinary style reached its climax and began its decline, and was thus peculiarly appropriate as a vehicle for a simultaneous critique of culinary excess and moral turpitude. This paper looks at the culinary style as revealed in the cookbooks of the period, using quantitative and qualitative methods, in order to define that style and to show its close links with the other arts, most notably painting, gardens and architecture. While the Mannerist style in England was somewhat apart from its Continental counterparts - and this is true of all the arts mentioned as well as the culinary - it was recognizably a part of the same movement.

Le théâtre de Shakespeare et de ses contemporains « regorge » de séquences où la gastronomie est mise en scène. Pourquoi ? L'une des raisons est que ces dramaturges écrivent à une période où le style culinaire à la mode arrive à son apogée et entame son déclin, c'est-à-dire que le moment est propice aux rapprochements entre excès culinaires et corruption morale. Cette étude aborde le style culinaire de la période tel que le révèlent les livres de cuisine. Par les méthodes quantitative et qualitative, l'analyse définit ce style et démontre les liens étroits entre le domaine culinaire et les autres arts, notamment la peinture, l'art des jardins et l'architecture. S'il est vrai que le style maniériste en Angleterre - aussi bien pour ce qui est des arts décoratifs que pour la cuisine - diffère quelque peu du maniérisme continental, il reste néanmoins une variante reconnaissable du modèle européen.

$\mathrm{T}$

he opening scene of Ben Jonson's Neptune's Triumph for the Return of Albion (1624) brings together a poet, who presents the masque, and a cook, who demands an anti-masque and, when the poet admits that he has none, provides his own; the figure of the cook has been read as Jonson's send-up of the pretensions of Inigo Jones, his collaborator on the court masques of the 1620s, and as the vehicle for a critique of public opinion on the subject of the failed Spanish marriage. ${ }^{1}$ But the choice of the cook as vehicle, and the fact that Jonson re-used many of the cook's lines from the unperformed masque in his later play, The Staple of News (1626), is suggestive of the cultural prominence of the table at this period. Plays by Shakespeare and his contemporaries teem with episodes which place gastronomy centre-stage: one scholar has counted banquet scenes occurring in 99

\footnotetext{
${ }^{1}$ The second view is set out in Sara Pearl, "Sounding to present occasions: Jonson's masques of 1620-5", in The Court Masque, ed. David Lindley, Manchester, Manchester University Press, 1984, p. 69-73.
} 
surviving plays from the period $1585-1642 .^{2}$ Jonson's masque is not the only text in which the cook and his food play a significant part: Furnace the cook in Massinger's A New Way to Pay Old Debts (c.1625) reappears throughout the play, usually to complain that his artistry is neglected by those who eat at his widowed mistress's table; in The City Madam (1632), the steward Holdfast's complaints about Lady Frugal's demands for expensive dishes and foreign cooks reveal her snobbery and extravagance. These playwrights were writing at a period when the fashionable culinary style reached its climax and began its decline, and was thus peculiarly appropriate as a vehicle for a simultaneous critique of culinary excess and moral turpitude. A similar phenomenon may be observed a century later, when the high Baroque style of cookery was being challenged by "nouvelle cuisine" (smaller, lighter dishes - there was nothing new in the 1970s): as one fashion went into decline and a new style began to take over, there was an upsurge in the use of cookery as a vehicle for moral and political satire, although in this case it found expression in periodicals and in prints rather than on the stage. ${ }^{3}$

A striking aspect of the complaints about cookery is their similarity at these two periods. The principal targets are the taste for very small morsels of food (as opposed to solid English joints of meat), and the wasteful use of vast quantities of meat to make sauces. Both of these are developed in Philip Massinger's The City Madam, with Holdfast's mention of pies made with carps' tongues, and the juices from three mutton carcasses used to make sauce for a single peacock. ${ }^{4}$ The emblematic dish of tiny morsels in the eighteenth century was made of pope's eyes (a nugget from the middle of a leg of mutton), while the extravagant sauce usually involved "quintessence" of ham or the juice of twenty-two partridges to sauce a brace of birds. ${ }^{5}$ Another

\footnotetext{
${ }^{2}$ Chris Meads, Banquets Set Forth: Banqueting in English Renaissance Drama, Manchester, Manchester University Press, 2001, p. 1. Meads is of course referring to the "banquet" as Tudor and Stuart England understood it, as the separate sweetmeat course after a dinner or supper, rather than as a feast.

3 This eighteenth-century manifestation of the congruence of culinary fashion and satire is treated in my "Politics in the Kitchen", Eighteenth-Century Life 23, NS 2, 1999, p. 71-83

4 Philip Massinger, The City Madam, ed. Cathy Shrank, London, Nick Hearn, 2005, II.i.3-6.

5 Both these examples are listed in William Verral's defence of the duke of Newcastle's French cook, Clouet, in Verral's Complete System of Cookery, London, the Author, 1759, p. xxx-xxxi. Further, earlier examples are enumerated in my "Politics in the Kitchen", op. cit. The date of the cookbook is much later than the stories told about Clouet: Verral had
} 
theme which is common to both periods is that of the cook as artist and virtuoso, a point developed by Jonson and Massinger. Such ridicule of cooks' pretensions was not merely gratuitous: the evidence of cookbooks suggests that grand cooks did indeed see themselves as artists, and their creations as art, while their patrons' appreciation was a sign of the latter's refined taste. The implicit link between visual arts and cookery is central to the anti-masque of Neptune's Triumph. It develops the culinary metaphor in visual as well as literary terms, since the ingredients for the "olla podrida" are personified by dancers: the artichoke, for instance, being danced by "a Fruicterer, with a cold red nose, / Like a blue fig"6, in a figure whose description evokes the anthropomorphized vegetables and fruits of Arcimboldo's portraits. It is easy to imagine the dancing figures in the anti-masque, as Arcimboldo's surviving drawings include the costume of a cook for a masque (c.1585). ${ }^{7}$ Cookery, literature, the dance: the intertwinings are a reminder of "the existence of an aesthetic ecosystem in which all arts participate". 8

My reference to Arcimboldo leads to the first observation concerning cookery as an integral part of the culture of its time. This is the intellectual curiosity which informs both. Far from being a very early form of Surrealism, an eccentric exception in the corpus of Mannerist painting, Arcimboldo's art was a way of exploring the natural world, an expression of the quest for knowledge which led patrons to create cabinets of curiosities, in a kind of "living" encyclopedia. ${ }^{9}$ The same mentality is visible in the text of cookery books themselves from the 1580 s to the 1650 s. Title-pages and texts refer to the book as a "jewel", "treasure", "treasury", "closet" or "cabinet", to the recipes as "conceits", "secrets", "experiments", and to

worked under him in the late 1730 , just as "nouvelle cuisine" was taking over in fashionable circles.

6 Ben Jonson, Neptune's Triumph, London, 1624, EEBO, STC (2nd ed.) 14779.

7 See catalogue n ${ }^{\circ}$ VII. 18: 3197F, in ed. Sylvia Ferino-Pagden, Arcimboldo, 1526-1593, Milan/Paris, Skira/Musée du Luxembourg, 2007, p. 253. The drawing is now in the Uffizi in Florence.

8 This expression is taken from L. E. Semler, The English Mannerist Poets and the Visual Arts, London, Associated University Presses, 1998, p. 7.

${ }^{9}$ On this, see the essay by Franz Kirchweger, "Entre art et nature : Arcimboldo et le monde des Kunstkammern", in ed. Sylvia Ferino-Pagden, Arcimboldo, op. cit., p. 189-194. On cabinets of curiosities in late sixteenth and early seventeenth-century England and Europe, see Marjorie Swann, Curiosities and Texts, Philadelphia, Pennsylvania University Press, 2001, p. 2-3, 18-27. 
the dishes produced as "conceits" and "devices". ${ }^{10}$ This vocabulary is often, but not exclusively, associated with medical lore and sugar cookery; that culinary recipes were also seen as "conceits" is made clear by the title-page of Dawson's book, The good huswifes Jewell (1587), which describes the contents as "most excellent and rare Devises for Conseites in Cookerie". Further confirmation of this is found in the dedicatory epistle to John Partridge's Treasurie of commodious Conceits (1573), which announces that the book teaches "the maner to make divers \& sundrie sortes of fine Conceites, as well of meates, as of Co[n]serves \& Marmalades". ${ }^{11}$ Such terminology remained frequent into the 1650 s (and many of the cookbooks which appeared between 1580 and 1630 remained in print until then), declining thereafter, although the terms "closet" or "cabinet" continued to feature in titles until the 1680 s, with "closet" last used in the compilation prefaced by John Shirley in 1687, by which time it was looking distinctly oldfashioned. This vocabulary, and some of the early texts, notably Partridge's book, derive partly from the medieval books of secrets, which contained a mix of formulae covering medicine, craftwork, alchemy, and magic. But while "secrets" and "experiments" evoke the past, "conceits" and "devices" bring us much closer to the arts of Elizabethan and Jacobean England. The same vocabulary was deployed in discussion on buildings and gardens: in 1593 John Norden wrote of Lord Burghley's London house as being "curiouslye beautified with rare devises", and of the "pleasant conceites within and without" at Theobalds. ${ }^{12}$ In literature and painting too, devices abound, in the flights of metaphysical poetry, and in painting most notably in the later portraits of Elizabeth I, filled with complex symbolic and allegorical references.

At this point we need to pause to consider the term "Mannerist" as applied to English arts. Traditionally, the labels "Elizabethan" and

\footnotetext{
${ }^{10}$ For examples of this vocabulary, see the title-page of J[ohn] Par[tridge], The Treasurie of commodious Conceits, and hidden Secrets, London, Richard Jones, 1573; that of Thomas Dawson, The good huswifes Jewell, London, John Wolfe for Edward White, 1587; also the title-pages and text in Hugh Plat, Delightes for Ladies, London, Peter Short, 1602, and John Murrell, A Daily Exercise for Ladies and Gentlewomen, London, widow Helme, 1617.

${ }^{11}$ John Partridge, The Treasurie of Commodious Conceites and hidden Secrets. Commonly called, The Good Huswives Closet of provision, for the health of her houshold, London, Richarde Jhones, 1584, Epistle, sig. Aiii v.

12 John Norden, Speculum Britanniae, 1593, quoted in Paula Henderson, The Tudor House and Garden, New Haven \& London, Yale University Press, 2005, p. 4
} 
"Jacobean" have been applied to English visual arts, rather than "Mannerist". The latter is a notoriously slippery term for art historians, used originally in a restrictive sense following Friedländer's definition in a lecture delivered in 1914 (published in 1925) on an "anticlassical" style in Italy from around 1520, then more largely to include the spread of Mannerist trends to France and the northern countries (which Friedländer also recognized), and more recently in a thoroughly ecumenical fashion which brings even English artists such as Hilliard within the Mannerist orbit. This is not the place to delve deeply into a definition of Mannerism, or to discuss its two phases, "mannerism" (the first generation), and "maniera" (the second generation), the latter, with its emphasis on self-conscious stylishness as a defining characteristic, being generally considered today as exemplifying the style. But it should be noted that many of the standard comments on Italian Mannerist art, pointing to its intellectual conceits and stylish virtuosity, the drive for elegance in its elongated figures or its refined surface detail, are equally applicable to many English artists such as Hilliard, Peake and Larkin. While a conservative use of the "Mannerist" label might apply it only to paintings obviously derived from Continental models, such as Scrots' 1546 portrait of Henry Howard, Eworth's 1550 portrait of Sir John Luttrell or Hoefnagel's 1569 allegorical painting of Queen Elizabeth and the Three Goddesses, a more open-ended usage would see a distinctly English version of Mannerism in the later emblematic portraits of Elizabeth, and in the elaborate costume pieces by such artists as Peake, with their “enamelled brilliance", to borrow Ellis Waterhouse's expression, which is perfectly applicable to portraits by Bronzino such as that of Eleonora of Toledo with her son (1545). ${ }^{13}$ Similar observations might be made concerning gardens, although the full-blown Mannerist garden with grottoes and elaborate waterworks on the model of Pratolino did not arrive in England until Salomon de Caus began work on the royal gardens at Somerset House and Greenwich in $1609 .{ }^{14}$

\footnotetext{
13 For the attributions of the Elizabethan paintings mentioned here, see Roy Strong, Gloriana: The Portraits of Elizabeth I, London, Pimlico, 2003, p. 68, 74. For the "enamelled brilliance", see Ellis Waterhouse, Painting in Britain, 1530-179o, 3rd edition, London, Penguin, 1978, p. 41.

14 The development of the "Mannerist" garden is described in Roy Strong, The Renaissance Garden in England (1979), London, Thames \& Hudson, 1998, p. 73-103. Strong characterizes the previous Elizabethan phase, as the "emblematic" garden (p. 71), replete with arcane allegorical references to the queen.
} 
Perhaps the greatest hindrance to using the term "Mannerist" for England is that the established vocabulary conjures up an immediate visual image, principally of pattern everywhere, on sitters' costumes and the carpets they stand on in portraits, on textiles and plasterwork in interiors, in the design of garden knots and in the layout of the garden and its buildings as a whole. And yet rejection of the term carries the idea that England was apart, scarcely touched by Continental Mannerism. Recent work has shown that the English approach was selective rather than ignorant: both in painting and in applied decoration the English were familiar with one of the Mannerist theorists, Lomazzo, whose emphasis on the idea incorporated into painting conformed to their desire to read a painting for its emblems. ${ }^{15}$ Just as the various studies in the volume edited by Lucy Gent, Albion's Classicism (1995), sought to demonstrate that the English approach to Italian Renaissance classicism was to appropriate it by adapting it to their requirements, instead of dismissing the English as naïvely backward borrowers, so we should perhaps posit a "vernacular Mannerism" along similar lines. This would bring together the intellectual conceits of emblem and allegory, the love of pattern and the wish to decipher images as well as texts, and the surface brilliance of contrasting textiles, with the crisp lace, soft fur, plush velvet and shiny silk curtains so accurately rendered in the portraits by William Larkin that they dazzle the viewer's eye. Such art is not wholly divorced from what is generally considered as more mainstream Mannerism: rather, it is an English variant, and I shall try to show how the culinary manifestation of this cultural moment is similarly both specifically English and part of a wider European movement.

Tracing a history of culinary styles is not an easy task, as the primary documents, the dishes, are gone forever, whereas the art historian has his primary documents, the paintings, to examine. Recipes bring us closest to the lost primary documents, and are indeed almost the only sources which can tell us how flavours and textures were combined to create dishes. But recipe collections do not provide a snapshot of what was being prepared in the kitchen at the date of

15 English familiarity with Lomazzo is discussed in David Howarth, Images of Rule: Art and Politics in the English Renaissance, 1485-1649, Berkeley \& Los Angeles, California University Press / London, Macmillan, 1997, p. 107; a similar observation is made concerning the decoration of garden structures in Paula Henderson, The Tudor House and Garden, op. cit., p. 163. 
publication: rather, their function was to record dishes which had been developed earlier, and to diffuse a particular style to a wider audience. This is not to say simply that the recipes were behind the times. Given that the late-Tudor cookbooks were compilations put together by the printers and booksellers rather than by any "author" whose name might appear on the title-page, the old was mixed with the relatively new, as the compilers ransacked manuscripts and other printed books to make up a collection. Even when the author began to take over from the bookseller, his method remained much the same. The result is that a huge book like Robert May's Accomplisht Cook, published in 166o, contains both recent recipes from the 1650 s and much earlier ones, whose sources can be traced back to recipes of the 1620 s and even the 1580s. May had a long career as a cook: he was born, according to the account of his life in his book, in 1588, although parish registers show that he was not baptized until 1592, a suspiciously long gap. He was thus about seventy years old when his book came out. ${ }^{16}$ The book is a complete record of the cookery he saw and practised throughout his career. The researcher's task is to sort out the new from the old, and to do this, the quantitative method offers a useful guide, provided it covers a long period. Quantitative analysis of ingredients brings out shifts over the long term, and enables us to situate developments within a coherent, if approximate, time-frame.

My statistical analysis covers cookery recipes from the early fourteenth century to the 1660 s, using all the medieval recipes currently available in print, and all the recipes in printed cookbooks from 1500 onwards. ${ }^{17}$ Excluded are the books devoted to confectionery,

\footnotetext{
${ }^{16}$ For these dates, see the introduction by Marcus Bell and Tom Jaine to the reprint of The Accomplisht Cook, Totnes, Prospect, 1994, p. 10, 12-13.

17 The recipe collections are as follows: "Diversa Cibaria" (c.1300-1325), reproduced in Constance B. Hieatt \& Sharon Butler (eds), Curye on Inglysch, EETS SS 8, 1985, p. 45-58; "Diversa Servicia" (c.1381), in Hieatt \& Butler, Curye on Inglysch, p. 62-79; "Utilis Coquinario" (c.1375-99), in Hieatt \& Butler, Curye on Inglysch, p. 83-91; the "Forme of Curye" (c.1400), in Hieatt \& Butler, Curye on Inglysch, p. 98-145; "Potage Dyvers I", (British Library, MS Harl. 279, c.1420), reproduced in ed. Thomas Austin, Two FifteenthCentury Cookery Books, EETS OS. 91, 1888, repr. 2000, p. 5-56; "Potage Dyvers II" (British Library, MS Harl. 4016, c.1440), in Austin, p. 69-107; "Ordinance of Pottage" (MS Yale Beinecke 163, c.1450), reproduced in Hieatt (ed.), An Ordinance of Pottage, London, Prospect, 1988, p. 35-107; MS Holkham 674 (c.1470), reproduced in ed. [Robina] Napier, $A$ Noble Boke off Cookry, London, Elliot Stock, 1882; Liber Cure Cocorum (British Library, MS Sloane 1986, c.1460-1480), ed. Richard Morris, Berlin, Philological Society, 1862; the "Awkbarow" collection (British Library, MS Harl. 5401, c.1480), reproduced in Hieatt, "The Middle English Culinary Recipes in MS Harley 5401: an Edition and Commentary", Medium Avum 65.1, 1996, p. 54-71; the printing by Pynson of the Noble Boke, London,
} 
which are the main success story of the early seventeenth century (a sign of the growing availability and popularity of sugar, at least amongst the better-off), books devoted to medicine which contain a few cookery recipes, and the small groups of recipes for confectionery and medicinal preparations which one finds in books otherwise devoted to cookery. This gives a total of 3909 recipes, with 388 recipes from the fourteenth century, 1088 from the fifteenth century, 957 from the sixteenth century (although 276 of these are found in the 1500 printing by Pynson of the Noble Boke, a manuscript collection dating back to at least the 1460s), 957 recipes for the period 1601 to 1659 , and 519 recipes from the 1660 s. My analysis of May's enormous book is still a work in progress, and is not included here. All the figures cited below represent the percentage of recipes (and not absolute numbers) in each collection which call for an ingredient.

English cookbook production started slowly, with no new printed books after Pynson's printing of a medieval manuscript until the appearance of $A$ Propre new booke of Cokery in 1545, and this was a small compilation of a mere 49 recipes. In the 1580 s and 1590 s, five books came out, offering a total of 632 recipes. This long publishing drought means that the changes shown by my statistics stand out, as medieval flavour preferences give way to late Tudor choices. But it also

1500, EEBO, STC (2nd ed.) 3297; A Propre new booke of cokery, London, Richard Lant \& Richarde Bankes, 1545, EEBO, STC (2nd ed.) 3365.5; A.W., A Booke of Cookrye (1584), London, Edward Allde, 1591, facs. repr. Amsterdam, Theatrum Orbis Terrarum, 1976; Thomas Dawson, The good huswifes Jewell, London, John Wolfe for Edward White, 1587, EEBO, STC (2nd ed.) 6391; The Second part of the good Hus-wives Jewell, London, E. Allde for Edward White, 1597, facs, repr. Amsterdam, Theatrum Orbis Terrarum, 1977; The Good Hous-wives Treasurie, London, Edwarde Allde, 1588, EEBO, STC (2nd ed.) 13854; The good Hus-wifes Handmaide for the Kitchin, London, Richard Jones, 1594, EEBO, STC (2nd ed.) 3298; G[ervase] M[arkham], The English huswife [Part 2 of Countrey contentments], London, J[ohn] B[eale] for R. Jackson, 1615; John Murrell, A New Booke of Cookerie, London, John Browne, 1617 (this edition adds 3 recipes to the 1615 text); John Murrell, The Second Booke of Cookerie, London, John Marriot, 1638 (this forms the second part of Murrels Two Books of Cookerie and Carving, ed. 5, 1638, but the text is identical to the first printing of 1628); The Ladies Cabinet Opened, London, M. P. for Richard Meighen, 1639, EEBO, STC (2nd ed.) 15119; W. J., A True Gentlewomans Delight, London, R. Norton, 1653; Jos. Cooper, The Art of Cookery Refin'd and Augmented, London, J. G. for R. Lowndes, 1654; The Ladies Companion, London, W. Bentley, 1654; W.M., The Compleat Cook (one of the three parts of The Queens Closet Opened), London, E. Tyler \& R. Holt, 1671, facs. repr. London, Prospect, 1984 (the text remained the same through all editions from 1655); Sir Theodore Mayerne [attr.], Archimagirus Anglo-Gallicus, [London], G. Bedell \& T. Collins, 1658; [William Rabisha], The whole Body of Cookery Dissected, London, George Calvert \& Ralph Simpson, 1682, facs. repr. Totnes, Prospect, 2003 (using only Part I, as the remaining parts reprint recipes from other sources; the text remained essentially unchanged from the first edition of 1661); Hannah Wolley, The Cooks Guide, London, Peter Dring, 1664. 
means that the beginning of these new developments is difficult to date from the recipes. Nevertheless, the recipes from 1545, although so limited in number, offer pointers to the early phase of the later style. The statistics show distinct peaks in the use of certain ingredients, with a noticeable rise in 1545 , culminating in the late 1620 s and beginning a pattern of decline thereafter. The general movement is never uniform: peaks and troughs occur within the period 1500-166o, but the trend of rise, climax and decline is nonetheless very obvious.

The first observation is the peak in the use of sweeteners. Sugar had always been a presence in English medieval cookery, used in up to $58 \%$ of recipes. But the pattern shows a falling-off of its use in the fifteenth century, reaching a low of $16 \%$ in around 1470 . Thereafter there is a rise which accelerates from 1545, culminating in its use in $89 \%$ of the recipes in the second book of John Murrell's Two Bookes of Cookerie and Carving of 1628 . With two exceptions, honey was never a very significant presence in medieval cookery, and by the late sixteenth century its use had virtually disappeared. Despite some fluctuations, the use of dried fruit (currants, raisins, prunes, dates) follows the same pattern as sugar, with a similar peak at $54 \%$ in 1628 . Thus there was a notable peak in the use of these sources of sweetness, and a sharp if uneven fall thereafter. It has long been known that sugar was perhaps the defining ingredient of Renaissance cookery, and it must be remembered that the statistics given here do not include the huge numbers of recipes for sweetmeats found in the cookbooks and in more specialized manuals of the early seventeenth century. Sugar was even more present on the table than these figures suggest.

Sugar was one component of the dominant flavour combinations. Another was acidity, supplied either by vinegar or verjuice, or by citrus juice, which might be from lemons or bitter oranges. Citrus juices were a new ingredient in English cookery in the sixteenth century, appearing for the first time in a cookbook in 1584, and making steady if uneven progress thereafter. This suggests a liking for a brighter flavour than that given by the more traditional acids. The peak of these is reached in 1615, with 60\% of the recipes in Markham's English Huswife calling for one or the other. It should be noted here that I exclude from the figures recipes for pickles, which begin to appear as scattered recipes early in the seventeenth century, and later occupy a chapter to themselves, as in William Rabisha's Whole Body of 
Cookery Dissected (1661), whose first "book" is devoted to 35 recipes for pickles. An examination of how the sweet and acid components were used reveals that they were very often combined. Although such combinations were used in medieval cookery, in up to $26 \%$ of recipes, but more often in around $15 \%$, they become much more prominent in the course of the sixteenth century, with twin peaks at $48 \%$ in 1615 (Markham) and 60\% in 1628 (Murrell, Book 2), with a subsequent decline in the 1650 s to medieval levels. The figures show a peculiar taste for a combination of flavours in which contrast rather than harmony is the aim. Acidity and sweetness do not cancel each other out; rather, each enhances the other, with two distinct flavours perceptible in one dish.

Other contributors to the flavours of the period were spices and herbs. Contrary to what Ken Albala suggests in his book on courtly cookery of the late Renaissance, The Banquet, English cookbooks do not favour native herbs rather than exotic spices. ${ }^{18}$ If anything, spice use increased somewhat in the sixteenth century: the average use of spices in the fourteenth and fifteenth centuries was in the range of $71 \%$ to $86 \%$, with an average of $79 \%$; in the period $1545-1628$ the range was between $61 \%$ and $97 \%$, with an average of $83 \%$. Herb use certainly increased: it rarely reaches $20 \%$ of medieval recipes, but after 1585 it is seldom below that figure, and more often close to $35 \%$, with a peak in Murrell's two books (1617 and 1628) at 46\% and 51\%. What did change was the preference for certain herbs and spices. Amongst herbs, the medieval favourites were parsley and sage, but our period chose parsley, rosemary and thyme. The preferred spices in medieval cookery recipes were saffron and ginger, but the second half of the sixteenth century chose pepper, ginger and cinnamon, and the early seventeenth century moved on again, to nutmeg and mace. Saffron, such an important spice in English medieval cookery, used in up to $53 \%$ of recipes, had almost disappeared by the early seventeenth century, being found in no more than about $2 \%$ of recipes. These choices point to a shift towards more "aromatic" spices and away from the "hotter" spices such as ginger.

The liking for aromas, and even heady aromas, is confirmed by the use during our period of rose-water, and, for the wealthy, musk and

\footnotetext{
18 See Ken Albala, The Banquet, Urbana \& Chicago, University of Illinois Press, 2007, p. 64-65.
} 
ambergris. Rosewater was occasionally used in medieval cookery (but is statistically insignificant); its use climbed in the sixteenth century to around $15 \%$ of recipes, and to around $25 \%$ in the first half of the seventeenth. Musk and ambergris were first used to perfume confectionery (Thomas Dawson's “marmalet of Quinces" in 1587 has an optional flavouring of musk $^{19}$ ), but soon migrated to culinary preparations. The first printed cookbook to use them is Murrell's second book, in 1628 , in which $10 \%$ of the recipes use musk, and $2 \%$ ambergris. Until the early 1660 s, recipes continue to call for them, with an average of $5 \%$ for musk, and $4 \%$ for ambergris. Musk (the glandular secretion of musk deer) has a strong perfume reminiscent of melons, and ambergris (the intestinal secretion of the sperm whale), while having very little aroma in its raw state, produces a powerful aroma of violets when incorporated into a dish. These two ingredients were notoriously expensive, and in the drama were a sure indication of reckless extravagance, as in The City Madam's reference to "pheasants drenched in ambergris" as part and parcel of "court gluttony". ${ }^{20}$

Sharp contrasts of flavour, and heady aromas, were further enhanced by the texture of smooth sauces, produced by the lavish use of butter and egg yolks as thickeners. Throughout the fourteenth and fifteenth centuries, butter had been a rare ingredient in cookery, used in under $5 \%$ of all recipes. But in $\mathbf{1 5 4 5}$ the leap in its use is startling. Suddenly butter is used in over $50 \%$ of recipes, and, with one exception, never falls below 40\%, reaching a peak in Murrell's two books in 1617 and 1628 of $73 \%$. The rise in the use of milk and cream is less striking, and its peak of around 30\% comes rather later, in the books of the 1650 s (compared with around $10 \%$ in medieval recipes). While part of this jump in the use of butter is attributable to an increasing number of recipes of pastry for pies and tarts, and to its use for filling up pies to exclude air so that they would keep, much of it went into the unctuous sauces which cloaked meats and the contents of many pies. What quantitative research tells us is that the cookery of our period was indeed a feast for the senses, with flavour, aroma and texture all playing a part. Such combinations also suggest a desire to overwhelm the diner with an array of sensual experience. The same

\footnotetext{
19 See Dawson, The good huswifes Jewell, 1587, ff. 33v-34r.

${ }^{20}$ Massinger, The City Madam, ed. Shrank, II.i.2-4.
} 
might be said to the way in which the contrasts of colour, pattern and texture are rendered in the portraits by Peake and Larkin.

While quantitative analysis can draw the broad outlines of a culinary style, qualitative micro-analysis is needed to make sense of the data. For reasons of space, I shall take one type of dish as exemplifying the style: a dish of chickens in sauce, variations on which are to be found in every cookbook from the 158 os to the 1620 . My principal example is a 1594 recipe for "Chickens with a Cawdel". ${ }^{21}$ The chickens are scalded and stuffed with parsley, and then put to simmer in salted water with dried fruit added. Once the chickens are tender, they are drained and served on sops with the fruit, covered in a sauce made of six egg yolks, a pint of vinegar, and four ounces of sugar (the recipes is unusual in giving precise quantities, at least for the sauce). What is striking here are the sharply contrasting flavours combined with a smooth sauce, the caudle of the recipe title. The point is not the natural flavours of chicken and parsley, but the artifice of the flavour and texture combination. As the statistics suggest, such combinations are frequent in late-Elizabethan cookbooks, and continue to be found until the 1650 . Variations on the theme involve a similarly sweet-sharp sauce, sometimes with the acid component emphasized by the use of fresh fruit such as gooseberries or grapes, sometimes with the sweet component highlighted, as in the aforementioned recipe. ${ }^{22}$ The aim is clearly to surprise the diner with these contrasts.

By the time we reach the cookbooks of the early seventeenth century, similar recipes are still a frequent presence, but the relatively simple garnish of the earlier books has given way to greater elaboration, a sign of the style reaching its peak. John Murrell's cookbook of 1615 offers two recipes for boiled capon which involve the same flavour combination of sweet and acid; between the two recipes are instructions for the garnish. This reinforces the flavour contrasts, and of course does so visually as well as on the gustatory level: the garnishes are sugar round the rim of the dish, candied orange peel dipped in sweet crumbs and carraway seeds, pomegranate seeds, currants and prunes dipped in sugar, sliced lemon, whole mace,

\footnotetext{
${ }^{21}$ See The good Huswifes Handmaide for the Kitchin, 1594, f. 6v.

22 For further examples, see A.W., A Booke of Cookrye, 1591, ff. 4v-5r, 6v; Dawson, The good huswifes Iewell, 1587, ff. 5r-v; The Second part of the good Hus-wives Jewell, 1597, p. [2-3].
} 
preserved barberries. ${ }^{23}$ "Any of these are fit to garnish your Dish", says the recipe: the cook could choose to emphasize either the sweet or the acid, or both, by his choice of garnish. Other versions of this type of dish add more ingredients, such as preserved lemon to lard the capon, or artichoke bottoms in the sauce, as well as the extra garnish. ${ }^{24}$

Pies and tarts were another vehicle with which to dazzle the diner through elaborate shapes and decorations, and through the hidden contents. Of course, many pies were designed to be kept and eaten cold, and for this butter was used to exclude air and thus preserve the contents. But pies to be consumed hot often contained a mix of meat or fish with spices, perhaps with dried fruit, to which was added a caudle-type sauce before the pie was served. ${ }^{25}$ The cookbooks of the late sixteenth and early seventeenth centuries do not offer much information on the decorative designs of pies and tarts, although literary references to the cook as architect make it clear that elaborate pie shapes were far from new in 1660, when the first illustrations for pie shapes and decorations appear in Robert May's book. ${ }^{26}$ While some of May's recipes offer newer flavours (essentially savoury), they also suggest combinations and variants which hark back to the Mannerist style, as for instance his pie of "Hare with a Pudding in his Belly", which combines the hare and its stuffing with sweet dried fruit, acid fresh fruit, and a "liquor" of a pound of sugar and a pint of claret or verjuice, spiced with whole mace. ${ }^{27}$ May's hare pie is elaborately shaped and decorated, as if to match its complex ingredients.

Sweet tarts and pies were equally elaborate, with the top crust slashed to allow glimpses of the contents, or with a pattern cut into the top to reveal the different colours of the fillings beneath. May's illustrations show several designs for these "cut-laid" tarts, with what are basically strapwork designs in pastry. May's recipes for "tart-stuff” - meaning the fruit preserves and other fillings for tarts - are in a direct line from late-Tudor books, although only one book suggests a

\footnotetext{
23 J[ohn] M[urrell], A New Booke of Cookerie, London, John Browne, 1615, p. 53-55.

24 See Murrell, A New Booke of Cookerie, 1615, p. 1-2; Murrels Two Books of Cookerie and Carving, 1638, p. 87-88.

25 Examples are found in Murrell, A New Booke of Cookerie, 1615, p. 15, 20-21, 22-23, 2324,25 .

${ }^{26}$ See Robert May, The Accomplisht Cook, London, R. W. for Nath. Brooke, 166o, p. 197, 201, 204, 206, 211, 215, 217, 218 for pie shapes; p. 220, 225, 227, 228, 229, 248 for sweet tart designs. Later editions increased the number of illustrations.

${ }^{27}$ May, The Accomplisht Cook, 166o, p. 206.
} 
tart with fillings of four colours (black, using prunes, green, using spinach juice, and white and yellow, using cream and egg yolks and whites); May adds green, yellow and red fruit preserves to the colours mentioned in the earlier work. ${ }^{28}$ The interlacing designs for the tops of cut-laid tarts, with their bright fillings visible between the lines of pastry, are most obviously linked to designs for knot gardens, which had been a feature of Tudor garden design since at least the 1530s. The similarities did not go unnoticed at the time, to judge from Sir Francis Bacon's acerbic comment about knots being "but toys; you may see as good sights many times in tarts", in his essay "Of Gardens" in 1625, at a time when knots were beginning to go out of fashion amongst the great. But tarts lagged behind garden fashions: most of the late Elizabethan cookbooks offer recipes for tarts with pastry covers, which leave the fruit whole or in slices, and for tarts without covers, which use a sweetened purée of fruit. ${ }^{29}$ The open tarts might be decorated with comfits, but elaborate pastry designs are only hinted at. It seems probable that the cut-laid tarts were a development of the late sixteenth century, part of the increasing elaboration which accompanied the climax of the Mannerist style.

Tarts were one element of visual as well as gustatory pleasure, but the greatest display of artistry was reserved for the banquet, the separate course of sweetmeats served after the meal, often in a banqueting house which might be in the garden or on the roof of the house. At the banquet too, the links between cookery and art were on display, and here the chronology of the Mannerist style is easier to identify. Recipes for sugar cookery and preserves are relatively rare in late-Elizabethan books, and the preserves are usually of two types: fruit kept in syrup, and stiff fruit purée, cooked with sugar until stiff enough to be cut into squares and kept in boxes. Marchpanes were flat cakes of almond paste, iced and perhaps gilded, and sugar itself appeared in the form of comfits (spices coated in sugar) and sugar-plate (a stiff mix of sugar and water, bound with gum tragacanth) which could be moulded into shapes. On grand court occasions elaborate decorative pieces in the form of marchpane towers and castles and sugar-plate chessboards or figures of beasts had been standard items since the days of

\footnotetext{
${ }^{28}$ For the recipes, see The Good Hous-wives Treasurie, 1588, sig. Bi-ii; May, The Accomplisht Cook, 1660, p. 233-235.

${ }^{29}$ See, for instance, the tart recipes in A.W., A Book of Cookrye, 1591, ff. 27r-29r.
} 
Henry VIII. ${ }^{30}$ These creations suggest that heraldic and chivalric themes were well to the fore, as indeed they were in great Tudor gardens. Although the cookbooks offer recipes for sugar-plate, and make suggestions for moulding it, the spectacular constructions made for the court were the work of professionals. But even at the lesser level of the cookbooks, as knowledge of sugar-work spread, the confections for the banquet became more ambitious, following the trend towards increasing elaboration which is visible in the ingredients and garnishes of dishes for the dinner-table.

By the early seventeenth century, recipes go much further than the earlier flat marchpanes. They propose more complex forms: marchpane moulded into shapes such as the "letters, knots, Armes, escocheons, beasts, birds, \& other fancies" suggested by Sir Hugh Plat, or the "Pyes, Birds, Baskets, and such like" in an anonymous work of $1608 .^{31}$ It could also be coloured to produce counterfeit "collops \& bacon" by alternating slabs of white and red paste before slicing, a recipe that appeared in 1617 and continued to be popular into the 1650 s. $^{32}$ Plat's suggestions link directly with Tudor garden decoration, and William Harrison's description of the fare amongst the nobility and at livery company feasts makes it clear that the fashion for moulded jellies and marchpanes was already current in the 1570 s. $^{33}$ More realistic moulding was possible with sugar paste made with gum tragacanth, and the seventeenth-century confectionery manuals suggest complex forms, such as artificial walnuts, with a cinnamontinted paste to make a shell in two halves, with a comfit or a "prettie

\footnotetext{
${ }^{30}$ A description of the sugar banquet for Elizabeth I at Elvetham in 1591, with castles and beasts, is given in Roy Strong, Feast, a History of Grand Eating, London, Jonathan Cape, 2002, p. 200-201. This book also reproduces the only surviving picture of such a sugar collation, for a German wedding in 1587, p. 199. The accounts for a supper and banquet for Henry VIII in 1527 mention a moated manor and a tower constructed on marchpane bases, and two sets of chess-boards and men; National Archives, SP 1/38, f. 116. A similar array of "devices" appeared at an entertainment for the French ambassadors given by Wolsey in the same year; see George Cavendish, The Life and Death of Cardinal Wolsey, ed. Richard S. Sylvester, EETS OS 243, 1959, p. 70-71.

${ }^{31}$ See Sir Hugh Plat, Delightes for Ladies, London, Peter Short, 1602, A12, A18; A Closet for Ladies and Gentlewomen, London, Arthur Johnson, 1608, p. 37-39.

$3^{2}$ See John Murrell, A Daily Exercise for Ladies and Gentlewomen, London, widow Helme, 1617, recipe 75; W.M., A Queens Delight (1655), facs. of 1671 edition, London, Prospect, 1984, p. 69.

33 William Harrison, The Description of England, ed. Georges Edelen, Washington D.C. \& New York, Folger Shakespeare Library \& Dover, 1994, p. 129.
} 
Posey [i.e. a short verse]", or a kernel of white sugar-paste inside. ${ }^{34}$ Another surprise for the guests was the cinnamon made of tinted and flavoured sugar paste, moulded around a stick to produce hollow cylinders. 35 Similarly realistic were the hollow fruits made of boiled sugar, painted to resemble real fruit; one book gives a list of prices and addresses for the colours and for gilding. ${ }^{36}$ Or one could make fruit by using fruit paste made with pippins to create "some with leaves, some like Plums with staulkes, and stones in them", moulded by hand, as a later recipe explains, although the original instructions are not particularly explicit. ${ }^{37}$ Plat even suggests coating moulded fowl with a mix of breadcrumbs, sugar and cinnamon, to make them "seem as if they were rosted and breaded", concluding that "a banquet may bee presented in the forme of a supper, being a very rare and strange device." 38

Research on the sources of Plat's book has shown that he drew extensively on a manuscript recipe collection by a clergyman, one "T.T."; Plat seems to have acquired the manuscript in the 1580 s, and he then added recipes and notes to it in preparation for his own work. ${ }^{39}$ Nearly all Plat's cookery recipes, and 27 of his 73 confectionery recipes (37\%), are from this manuscript, which contains dates in T.T.'s hand around 1560. The boxed fruit pastes, the plates and saucers made of sugar-plate, the moulded marchpane or sugar shapes, are all taken from this earlier manuscript. The early seventeenth-century confectionery manuals diffused a style which was already current, and circulating via manuscript recipes, half a century earlier. But these new books also presented more recent fashions. Plat's counterfeited roast fowl came from one of the queen's cooks, a man called Webber, whom Plat met in 1595, and the imitation fruits, nuts and spices do not appear before 1600 . Thus there seems to be a move away from the

\footnotetext{
34 See A Closet, op. cit., p. 33-34; Murrell, Daily Exercise, op. cit., recipe 80; The Ladies Companion, London, W. Bentley, 1654, p. 39; W.M., A Queens Delight, op. cit., p. 69.

35 See $A$ Closet, op. cit., p. 26. Markham also gives a recipe, but it is far less informative, see The English Huswife, London, Roger Jackson, 1615, p. 73-74; the recipe in The Ladies Cabinet Opened, London, M.P. for Richard Meighen, 1639, p. 53, gilds the sticks.

${ }^{36}$ See $A$ Closet, op. cit., p. 39-40, 24-25; The Ladies Cabinet Opened, op. cit., p. 55-57.

${ }^{37}$ Murrell, Daily Exercise, op. cit., recipe 77; Archimagirus Anglo-Gallicus, London, G. Bedell \& T. Collins, 1658 , p. 88-89.

$3^{8}$ Plat, Delightes for Ladies, op. cit., A10.

39 See Malcolm Thick, "A Close Look at the Composition of Sir Hugh Plat's Delightes for Ladies”, in Eileen White (ed.), The English Cookery Book: Historical Essays, Totnes, Prospect, 2004, p. 55-71.
} 
heraldic and emblematic moulded marchpanes of the middle of the sixteenth century, towards more illusionistic representations of food items, in a self-conscious conflation of the real and the artificial. Seeing and eating these fake fruits, spices and roasts was to experience the double pleasure of being deceived by the visual illusion, and undeceived by the gustatory revelation.

The banquet provides a summary of the Mannerist ethos, with its clever facsimiles which were designed to impress, to surprise, and to amuse the viewer. It also brought together the natural and the artificial, showing how the cook's artistry could improve on nature, just as Arcimboldo's anthropomorphized fruits and vegetables expressed the artist's mastery over the natural world. In the same way, the dishes described above showed off the cook's transformative power: the natural flavours of meat or fish were only one component of a multilayered, richly contrasting medley of savoury, sweet, sour, and aromatic. The emphasis in the cookbooks' discourse on "devices" and "conceits" seems appropriate not merely to the decorative dishes, but to the style of cookery in its entirety. The artful combinations of flavours, and the attention-seeking presentations, belong to the same Mannerist aesthetic defined by Ken Albala in his comparison of an Italian dinner described in Rossetti's Dello Scalco in 1584, and Mannerist paintings by Pontormo, Bronzino and Michelangelo. ${ }^{40}$ The recipes and the dishes in England are different from the Italian counterparts, but are nevertheless another expression of what I described above as "vernacular Mannerism".

Gilly LEHMANN

University of Franche-Comté, Besançon (retired)

\footnotetext{
${ }^{40}$ Albala, The Banquet, op. cit., p. 12-19.
} 